\title{
Do Relationships Matter in Export Performance Enhancement? Evidences From Moroccan SMEs
}

\author{
Saif Allah Allouani, Houcine Berbou \\ Université Hassan 1er, Settat, Morocco
}

\begin{abstract}
This article addresses the concern of export performance among Moroccan SMEs through the paradigmatic lens of the resource based view (RBV) and international relationship marketing. Limited research exists on relational determinants of export performance, especially in developing countries. Furthermore, literature has been dominated during the last decade by the economic perspective. Yet, an increased attention has turned to the RBV as well as the relational perspective. Highlighting this gap, the study aims two objectives: First, to understand the scope and the nature of relational determinants, deemed as key resources, of export performance. Second, to examine which other internal and market factors are intervening as significant antecedents of the relational factors. Drawing from a literature review outcomes and an in-depth interview endeavor conducted among 20 exporting firms' managers, a conceptual framework has been proposed. It's argued that exporting firms would reach great export performance by fostering successful cross-border inter-firm relationships. More specifically, the study highlight three main relational constructs, namely contractual governance, relational governance, and relationship performance. Linguistic abilities, attitude toward risk and export experience are suggested as managerial antecedents. While competitive intensity and market uncertainty are supposed to intervene as external antecedents. Several hypotheses are suggested. The unit of analysis is a selected export venture. A further inquiry of the overall study is to offer hypotheses test throughout quantitative survey.
\end{abstract}

Keywords: SME, export performance, RBV, inter-organizational relationships, relationship governance

\section{Introduction}

In current world economy, global market integration has been fostered by the removal of various trade barriers and the establishment of several bilateral and multilateral free trade agreements in both developed and developing countries. Morocco is bound by free trade agreements with several developed countries, and it is an established supplier of several products (e.g., textile-clothing, agricultural and chemical) to European and North American markets. Exportations contribute about $40.65 \%$ to the Moroccan GDP making Moroccan future economic growth vastly dependent on the results of the export activity. However, in recent years, Morocco's export performance has been lackluster (Walkenhorst, Peter, \& Malouche, 2006, p. 4). As a result, the country

Saif Allah Allouani, Ph.D. candidate, Ecole Nationale de Commerce et de Gestion(ENCG), Université Hassan 1er. Houcine Berbou, Doctor, Ecole Nationale de Commerce et de Gestion (ENCG), Université Hassan 1er. Correspondence concerning this article should be addressed to Saif Allah Allouani, 2 Rue Badie, Derb Belghali Route Imouzzer, Fès, Morocco. E-mail: saif.allouani@gmail.com. 
has lost world market share in merchandise exports. This regression is partially due to the increase of competitive pressure from other countries (namely Turkey and China) and the rapid change in international context. Thus, Moroccan exporters have to strengthen their export strategies to secure international competitiveness.

The Moroccan situation represents one of an emergent economy setting characterized by high SMEs density. SMEs represent more than 93\% of Moroccan enterprises and play a leading role in export dynamics. Export is the dominant mode of entry into the international market. Due to limited resources, SMEs are facing numerous problems in maintaining a competitive position.

In this context, study of export performance of SMEs appears both necessary and timely, for two main reasons. The first is the paucity of research upon the export performance in developing countries (Sousa, Martínez-López, \& Coelho, 2008). The second is to provide managers and policy makers with useful insights into the key factors driving the export performance of SMEs. While the core purpose of the research is to shed light on the relevant determinants of export performance in the Moroccan context, we focus on determinants related to cross border relationship management. The theoretical underpinning of the research is the resources based view (RBV) and the relational paradigm.

This paper is structured as follows. First, the rationale for the study is introduced by highlighting gaps in the export performance literature. Afterward, the theoretical underpinning of the research is exposed. In the third section, the proposed conceptual framework and related propositions are discussed. Contributions and limitations of the research are mentioned in the conclusion.

\section{Export Performance Literature}

Export literature has been criticized for not yielding a broadly accepted model on export performance (Leonidou, Katsikeas, \& Samiee, 2002). As mentioned by several scholars on their literature reviews (Aaby \& Slater, 1989; Zou \& Stan, 1998; Ruppenthal \& Bausch, 2009), the available studies provide highly fragmented and inconsistent results. The main reasons for inconstancy are variation in empirical methods, underlying theoretical concepts, definitions of variables and differences in measurement scales. Thus, it has been claimed that export performance has remained as "one of the most widely researched and least understood areas of international marketing” (Sousa et al., 2008, p. 344). In recent research appeals, international marketing and export performance researchers have been encouraged to be theoretically driven (Douglas \& Craig, 2006; Styles, Patterson, \& Ahmed, 2008).

Historically, studies on export performance have been dominated by the economic view, throughout the structure-conduct-performance (SCP) framework (Cavusgil \& Zou, 1994; Zou \& Cavusgil, 1996). More recently, two perspectives have gained growing interest: the RBV approach (Morgan, Kaleka, \& Katsikeas, 2004) and the relationship marketing paradigm (Style \& Ambler, 2000; Samiee \& Walters, 2001). These complementary approaches have been adopted in this study.

A salient gap in export performance research is its over concentration in developed countries (Sousa et al., 2008). Despite the growing body of research done outside the USA, limited work has been done in developing countries (Sousa et al., 2008; Matanda \& Freeman, 2009). Researchers have also called for the need to test marketing theory in developing countries (Sousa et al., 2008; Wheeler, Ibeh, \& Dimitratos, 2008). The 
aforementioned points provide the rationale for this study.

\section{The RBV, Resources as Key Drivers of Performance}

The RBV is increasingly recognized as a key theoretical paradigm in the export performance literature (Matanda \& Freeman, 2010). This theoretical innovation (Peng, 2001) calls for viewing the firm not in the light of its strategies but as a unique bundle of tangible and intangible resources (Zou, Fang, \& Zhao, 2003). The core premise is that firm's resources determine its competitive advantage (Peteraf, 1993; Wernerfelt, 1984) rather than its strategy.

According to the RBV perspective, sustainable competitive advantage can be derived by firms possessing resources and capabilities that are valuable, rare, imperfectly imitable, and non-substitutable (Barney, 1991). In line with this perspective, a wide range of individual, social and organizational phenomena within the firm might be potential sources of sustained competitive advantage (Barney, 1991).

In the specific context of this study, it is argued that SME would achieve high export performance when it possesses strong internal resources and is able to utilize these resources to obtain a competitive advantage. More specifically, the focus is on relational resources and their antecedents.

\section{Relational Capabilities as a Key Internal Resource}

Within the RBV tenets, recent studies view that the successful handling of business relationships with overseas customers is a valuable source of competitive advantage in international markets (Wu, Sinkovics, Cavusgil, \& Roath, 2007). Key internal resources, such as relationships and networks, enable SMEs exporters to overcome international constraints. Thus, conceptually, inter-organizational relationships could be deemed as a key organizational capability (Matanda \& Freeman, 2009; Freeman \& Cavusgil, 2007; Peng, 2001). According to the relational perspective, to overcome the current competitive and hostile business landscape, international firms must develop and maintain successful business relationships with international clients (Cannon, Achrol, \& Gundlach, 2000; Morgan \& Hunt, 1994). According to Lu (2009), close business relationships can offer the firms a variety of benefits, including improvements in efficiency, reduced costs, increased productivity, flexibility, organizational learning, and knowledge transfer (Claro, Hagelaar, \& Omta, 2003). In Moroccan context, a study done by Kalika, Guilloux, and Laval (1998) examined the interplay between SMEs structure complexity and the intensity of relationships with a French partner. The study confirmed a significant positive association between the organizational learning done by the SME and the intensity of the business relationship.

The relational view of cross border business relationships is drawn from the relationship marketing paradigm. Since its appearance in the late 1980s, relationship marketing has been considered by marketing scholars as a powerful new paradigm which supplements the marketing mix traditional paradigm (Gronroos, 1994). In an international context, many scholars encourage the adoption of the relational paradigm to apprehend export performance; the development of mutually beneficial, trust based relationships with foreign partners was viewed as a source of strong potential sources of competitive advantage (Balabanis, Theodosiou, \& Katsikea, 2004). For example, Leonidou (2003, p. 138) has argued that "export should be seen as a process of establishing, developing, and sustaining customer relationships in international markets at both strategic and tactical levels". While Leonidou, Katsikeas, and Hadjimarcou (2002, p. 108) suggest firms to "treat exporting as a bundle of business relationships". 
However, scholars underlie the scarcity of studies addressing the dynamic of cross border business relationships. Graig and Douglass (1997, p. 297) have concluded that "while the management of buyer-seller relationships has become an increasingly important issue..., the complexity of buyer-seller relationships in an international context has been sadly neglected”. The paucity of research on international relationship marketing is probably due to the inherent complexity of the relationship phenomenon. This idea is highlighted by Samiee and Walters (2003, p. 195) who argue that:

Relationships are complex phenomena which can be examined from a variety of perspectives in terms of theoretical frameworks, constructs, and methodology. When combined with firm-related factors and marketing strategy consideration, the range of topics and issues that might be explored increases exponentially.

To understand the scope and the nature of relationship determinants of export performance, we have relied on Samiee and Walters (2003) literature review which we supplement with a non-exhaustive review of recent studies published during the last decade. This review yields two main and related constructs as salient relational drivers of export performance, namely relationship performance and relationship governance. Relationship performance or exchange performance has been used as a main construct in several studies. It refers to the quality of the relationship (Obadia, Vida, \& Reardon, 2008; Skarmeas \& Matthew, 2008), or its intensity (Styles \& Ambler, 2000). According to Donada and Nogatchewsky (2005), relationship performance could be measured throughout four dimensions: economic, harmonious cooperation (absence of conflict, trust...), satisfaction of exchange partners, and expectation of continuity.

Relationship performance. Relationship performance has been used as a direct predictor of export performance (Obadia, Vida, \& Reardon, 2008; Beaujanot, Lockshin, \& Quester, 2006) or a key dependant variable (Ahmed, 2009; Ferguson, Paulin, \& Bergeron, 2005; Leonidou, Barnes, \& Talias, 2006; Leonidou \& Katsikeas, 2003; Aulakh \& Gençtürk, 2008; Lage, Silva, \& Styles, 2009). The after mentioned studies confirmed the positive association between relationship performance and export performance.

Relationship governance. The relationship governance deserves attention because export ventures are vulnerable with the risk of failure and shortcomings (Deligonul et al., 2005). Firms, in the intentional arena, are exposed to opportunism, which ultimately impacts on performance and survival in foreign markets (Cannon, Achrol, \& Gundlach, 2000; Cavusgil, Deligonul, \& Zhang, 2004). Viewed from this angle, constructing appropriate structures to govern and safeguard business relationships should be at the heart of exporting firm's attention (Weitz \& Jap, 1995).

Relationship governance is a salient construct in numerous studies addressing cross border business relationships. It refers to the formal and informal rules of exchange between partners (Griffith \& Myers, 2005; Wathne \& Heide, 2004). As deducted from the examined studies, two forms of governance mechanism are involved in cross-border inter-firm exchange: contractual-based and relational-based governance (Cavusgil, Deligonul, \& Zhang, 2004; Gençtürk \& Aulakh, 2006; Roath, Miller, \& Cavusgil, 2002; Wu, Sinkovics, Cavusgil, \& Roath, 2007; Ferguson, Paulin, \& Bergeron, 2005).

The theoretical roots of contractual based on governance are drawn from the transactional cost economy (TCE) perspective. According to this theory, firms engaging in inter-organizational relationships face potential opportunistic behavior from partners, and several exchange hazards including specialized asset investments, 
difficulty in performance measurement, and uncertainty (Williamson, 1985, 1991, 1996). In this context, managers develop governance arrangements that stipulate "comprehensive contracting whereby all relevant future contingencies pertaining to the supply of a good or service are described and discounted with respect to both likelihood and futurity” (Williamson, 1985, p. 69).

According to Roath, Miller, and Cavusgil (2002), a contract is generally a detailed agreement that stipulates an offer made and accepted between two or more parties and deemed beneficial to each party involved. It enables the firms to monitor, control, and assess each other's behaviors (Wu, Rudolf, Sinkovics, \& Roath, 2007).

From an exporting perspective, contractual arrangements play a significant role in facilitating the management of cross-border business relationships. Contractual arrangements help structure the relationships between exporters and foreign counterparts, by reducing risks and uncertainties in those relationships (Bello \& Williamson, 1985; Cavusgil, Deligonul, \& Zhang, 2004; Zhang, Cavusgil, \& Roath, 2003).

The transactional view of exchange has been criticized for being too rational and for ignoring social dimensions within the exchange like trust and commitment. In contrast, the relational exchange perspective highlights those social phenomena. Based on Macaulay (1963) critics toward contract's effectiveness and the seminal contribution of Macneil (1980), growing attention has been given to relational governance in relationship exchange. Relational-based governance or "relationalism" (term used by Bello, Chelariu, \& Zhang, 2003) involve a critical set of relational norms that forms a hallmark of relational exchange (Gundlach \& Achrol, 1993). Norms represent "a principle of right action binding upon the members of a group and are serving to guide, control, or regulate proper and acceptable behavior” (Macneil, 1980, p. 38).

Relational-based governance is considered as a multidimensional phenomenon (Heide \& John, 1992), Although the increasing number of studies addressing relational norms, no consensus is achieved on the definition of relational based governance (Heide \& John, 1990; Zhang, Cavusgil, \& Roath, 2003; Iven \& Blois, 2004). Scholars established the significant role of relational governance in improving exchange performance (Paulin \& Bergeron, 2005; Heide \& John, 1990). Relational norms hinder opportunistic behaviors (Cannon, Achrol, \& Gundlach, 2000; Joshi \& Stump, 1999; Cavusgil, Deligonul, \& Zhang, 2004) and facilitate exchange under high uncertainty conditions (Poppo \& Zenger, 2002; Centruk \& Aulakh, 2006). In line with this perspective, relational governance represents a valuable asset to help firms in acquiring competitive advantage in foreign markets; hence, the development and maintenance of relational-based governance require a considerable allocation of time and other resources (Larson, 1992).

Despite the increasing recognition of the relational-based governance in enhancing inter-organizational relationship performance, limited attention has been addressed to its role in exporting research (Leonidou, Katsikeas, \& Hadjimarcou, 2002) especially in the specific context of developing countries. Thus, the adoption of the relational perspective is deemed appropriate in this study from both academic and practical interest.

\section{Conceptual Framework and Hypothesis Development}

Drawing from existing knowledge in export literature, international relationship marketing paradigm, a conceptual framework has been proposed. It is argued that venture export performance is directly influenced by the performance of the relationship between exporter firms and its foreign partner. In addition, it's also argued that relationship performance is influenced by the effectiveness of governance mode. We examine also, in this 
conceptual framework, the antecedent of governance mode mechanism, especially those related to the firm's management and the environment of exchange (see Figure 1).

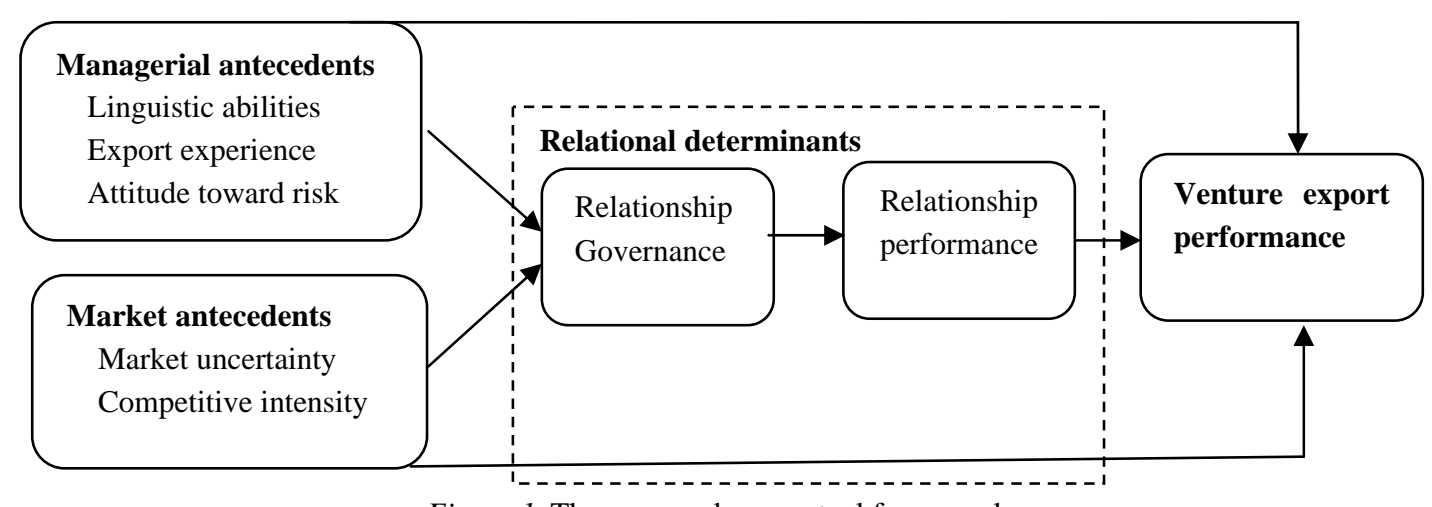

Figure 1. The proposed conceptual framework.

A set of in-depth interviews has been conducted with 10 random selected SMEs in order to contextualize the proposed conceptual model. This qualitative exploratory phase improved the understanding of the complex and idiosyncratic nature of cross border relationships especially in the Moroccan context. In addition, this qualitative study helped to narrow the scope of study, to focus and determine the relevant variables to be discussed during the following quantitative phase. A discussion of the variables derived from the literature review, and the pilot study as investigated in the qualitative study, is presented in the following paragraphs.

\section{Export Performance Measurement}

Export performance is the main dependant construct of our study, though not clearly mentioned in our research objectives, two main issues are involved in the study: the measurement and the unit of analysis of export performance. Concerning the first issue, among the plethora of available scales, the EXPERF scale developed by Zou et al. (1998) were chosen for two reasons: first, the scale captures three dimensions of export performance including economic, strategic and attitudinal indicators, which is coherent with the interviewed managers' perceptions. The second stipulate that, to the best of our knowledge, this scale has not been empirically tested in a developing countries context. Concerning the level of analysis, Cavusgil and Zou (1994) argued that no consensus is achieved about the "right level" of export performance analysis. We adopted, in this study, the export venture as the unit of analysis as it has been recommended by many scholars like Madsen (1989), Cavusgil and Zou (1994), and Lage (1998).

\section{Relationship Performance}

Result from the exploratory study has confirmed the potential role of relationship performance on the international success of SMEs. In addition, relationship performance encompasses the financial and non-financial dimensions. Then, we propose:

Proposition 1: The performance of the relationship with the foreign partner is positively associated with the performance of the export venture.

\section{Norm-Based and Contractual-Based Governance}

The exploratory study confirmed the coexistence of two governance mechanisms stated in the literature. While aware of the importance of contractual arrangement in managing export relationships, interviewed 
managers declare the usage of varying degrees of formalization as important. Concerning relational norms, the finding of the exploratory study highlights three salient norms among those suggested in the literature namely: (1) trust indicated by Zhang, Cavusgil, and Roath (2003); (2) information exchange as indicated by Anderson and Narus (1990); and (3) flexibility as indicated by Poppo and Zenger (2002). According to the interviewed managers, the extent of the mentioned three norms determines the soundness of the relationships with international clients. Thus according to this research, relational governance has to be considered as a higher order construct specifically with reference to trust, information exchange and flexibility. This leads us to the following propositions:

Proposition 2a: Formalization is positively associated with export relationship performance.

Proposition 2b: Norm-based governance is positively associated with export relationship performance.

\section{Managerial Antecedents}

Among the strategic resources of the SMEs, related to the manager play an important role. The manager in person according to Stoian (2010) is considered as the main resource in SMEs context. Finding of the exploratory study suggested three managerial features that are important which have already been proposed in the literature as determinants of export performance, namely: (1) linguistic abilities; (2) international experience; and (3) attitude toward risk.

Linguistic ability. The direct link between manager's linguistic abilities and export performance has been established by several scholars (Ursic and Czinkota, 1989; Leonidou, Katsikeas \& Piercy, 1998; Williams and Chaston, 2004). As mentioned by Williams and Chaston (2004, p. 464), “... a lack of foreign language knowledge may contribute to managers' perceptions of 'psychological distance' between their home and overseas markets, and may therefore inhibit the international development process". In this study the manger's linguistic ability were determined as an antecedent of successful export relationship. Thus, the following proposals:

Proposition 3a: Manager's linguistic ability is positively associated with the export relationship performance.

Proposition 3b: Manager's linguistic ability is positively associated with the degree of formalization in export exchange.

Proposition 3c: Manager's linguistic ability is positively associated with the extent of relational norms in export relationship.

Proposition 3d: Manager's linguistic ability is positively associated with the venture export performance.

Manager's export experience. Export experience has been considered by scholars as a key driver of export performance (Aaby \& Slater, 1989; Cavusgil \& Zou, 1994). In the specific context of this study, the eventual link between export experience and the relational determinants of the venture export performance were examined, based on which the proposals to follow is suggested:

Proposition 4a: Manager's international experience is positively associated with export relationship performance.

Proposition 4b: Manager's international experience is positively associated with the degree of formalization in export exchange. 
Proposition 4c: Manager's international experience is positively associated with the extent of relational norms in export relationship.

Proposition 4d: Manager's international experience is positively associated with venture export performance.

Attitude toward the risk. Exporting carries higher risks than domestic sales, (Deligonul et al., 2005). The link between risk tolerance and export performance has been examined by several scholars including Leonidou, Katsikeas and Piercy (1998). Findings from the study suggest a significant link between the manager's risk tolerance and the governance mode of relationship adopted and the relationship performance with the foreign client. This study attempts to study manager's risk tolerance as a managerial antecedent of relationship governance mode. It is proposed as follows:

Proposition 5a: There is a positive link between manager's risk tolerance and export relationship performance.

Proposition 5b: There is a negative link between manager's risk tolerance and the degree of formalization in export exchange.

Proposition 5c: There is a positive link between managers risk tolerance and the extent of relational norms in the export relationship.

Proposition 5d: There is a positive link between a manager's international experience and venture export performance.

\section{Market Antecedent}

According to Katsikeas, Leonidou, and Morgan (2000) and Matanda and Freeman (2009) limited empirical work has focused on the link between environmental factors and export performance. Drawing from the exploratory study and the literature review, this research paper focuses on two aspects of the market namely: (1) uncertainty; and (2) competitive intensity.

Competitive intensity. Export marketing scholars have emphasized the role of competitive intensity in determining the performance of exporters (Kaleka \& Katsikeas, 1995; O’Cass \& Julian, 2003). Competitive intensity refers to the availability of opportunities and resources that can provide firms with a competitive advantage (Matanda \& freeman, 2009). Moroccan SMEs are facing great challenges to deal with increasing competitive pressure in their endeavor to keep a foothold in foreign markets. Moroccan exporters require deploying more resources to enhance product and service offerings to meet customer needs and demands. Specifically appropriate management of relationships with foreign partners is required. This study, examined how competitive intensity would influence relational determinants of export performance. Based on the research findings the following is proposed:

Proposition 6a: Competitive intensity is negatively associated with the venture export performance.

Proposition 6b: Competitive intensity is negatively associated with relational-based governance.

Proposition 6c: Competitive intensity is positively associated with contractual-based governance.

Proposition 6d: Competitive intensity is negatively associated with relationship performance.

Market uncertainty. Market uncertainty is related to unanticipated changes in the relevant conditions of the host market served by the exporter (Centruk \& Aulakh, 2006). Matanda and Freeman (2009) indicate that 
market uncertainty is usually conceptualized as a multidimensional construct including several aspects. The effect of uncertainty in export relationship management has been examined by Centruk and Aulakh (2006), Cavusgil, Deligonul, and Zhang (2004), Leonidou, Barnes, and Talias (2006) and several scholars. The mentioned studies argue that, under uncertainty, both relational-based and contractual-based governance are employed to enhance relationship performance. In this study, it is conceptualized that a three-dimensional construct comprising: (1) market turbulence; (2) market volatility; and (3) legal uncertainty exist. Based on the research it is proposed that:

Proposition 7a: Market uncertainty significantly influences formalization of contract.

Proposition 7b: Market uncertainty significantly influences relational-based governance.

Proposition 7c: Market uncertainty significantly influences venture export performance.

\section{Conclusion}

The research outcomes would contribute to advancing the scant international marketing literature on the export performance in developing countries' context. In terms of theoretical foundations, the research combined the explanatory power of two well established paradigms, namely the RBV and relationship marketing perspective. Several scholars have called for studies that produce a comprehensive understanding of relationship issues in international business setting (Bello, Chelariu, \& Zhang, 2003; Gençtürk \& Aulakh, 2006; Leonidou, 2003). Hence, a major contribution of the study is an integrated framework that simultaneously assesses the determinants and consequences of exporter/importer's relationship performance. More specifically, the study examines how firms can successfully manage international inter-firm relationships whilst achieving optimal international performance.

At this stage of the exploration endeavor, the research outcomes confirm that both contractual-based and relational-based governance mechanisms exist in cross-border relationships between Moroccan firms and their overseas clients. In addition, these governance mechanisms are likely to be driven by internal and external environmental characteristics.

In term of practical contribution, the ambition of this study is to provide international business practitioners with a comprehensive understanding of the relevant factors determining their exporting success. It emphasizes the crucial rule of relationship management. The main idea is that successful handling of business relationships with overseas customers is a valuable source of competitive advantage in an increasingly integrated global marketplace.

Despite the strong theoretical foundation and significant implications for business practice, the research findings should be treated with caution for at least two reasons. First, qualitative data collection investigated only the perspective of exporters, and the data are cross-sectional in nature. Furthermore, as the unit of analysis is a single export venture, the research findings should be interpreted and generalized at a relationship and not at the firm level. Second, the proposed conceptual framework does not take into account other potential relevant drivers of SMEs export performance, such as organizational characteristics, government politics, the international marketing mix and cultural factors. Moreover, the recent export consortium phenomenon deserves more interest, especially from a relational perspective.

In the next stage of the study, the propositions of this conceptual framework will be tested. A structural 
equation modeling method will be used to assess and refine the proposed model.

\section{References}

Aaby, N. E., \& Slater, F. (1989). Management influences on export: A review of the empirical literature 1978-1988. International Marketing Review, 6(4), 53-68.

Ahmed, F. (2009). Reciprocal effects of commitment on exporter-importer relationships. Journal of Relationship Marketing, 8(1), $2-16$.

Ambler, T., Styles C., \& Xiucun, W. (1999). The effect of channel relationships and guanxi on the performance of inter-province export ventures in the People's Republic of China. International Journal of Research in Marketing, 16(1), 75-87.

Balabanis, G., Theodosiou, M., \& Katsikea, S. E. (2004). Export marketing: Developments and a research agenda. International Marketing Review, 21(4/5), 353-377.

Barney, J. (1991). Firm resources and sustained competitive advantage. Journal of Management, 17(1), 99-120.

Bello, C., Chelariu, C., \& Zhang, L. (2003). The antecedents and performance consequences of relationalism in export distribution channels. Journal of Business Research, 56(1), 1-16.

Cannon, J. P., \& Perreault, D. (1999). Buyer-seller relationships in business markets. Journal of Marketing Research, 36(4), 439-460.

Cannon, J. P., Achrol, S., \& Gundlach, G. T. (2000). Contracts, norms, and plural form governance. Journal of the Academy of Marketing Science, 28(2), 180-194.

Chetty, S. K., \& Hamilton, R. T. (1993). Firm-level determinants of export performance: A meta-analysis. International Marketing Review, 10(3), 26-34.

Claro, D. P., \& Omta, G. (2003). The determinants of relational governance and performance: How to manage business relationships? Industrial Marketing Management, 32(8), 703-716.

Craig, C. S., \& Douglas, S. P. (2006). Conducting international marketing research in the twenty-first century. International Marketing Review, 18(1), 80-90.

Deligonul, S., \& Cavusgil, S. T. (2006). Legal versus relational ordering in chanel governance: The case of the manufacturer and its foreign distributor. Advances in International Marketing, 16, 49-79.

Deligonul, S., \& Zhang, C. (2004). Curbing foreign distributor opportunism: An examination of trust, contracts, and the legal environment in international channel relationships. Journal of International Marketing, 12(2), 7-27.

Dhanaraj, C., \& Beamish, P. W. (2003). A resource-based approach to the study of export performance. Journal of Small Business Management, 41(3), 242-261.

Donada, C., \& Nogatchewcky, G. (2005). Vingt ans de recherches empiriques en marketing sur la performance des relations client-fournisseur. Recherche et Applications en Marketing, 20(4), 71-96.

Gençtürk, E. F., \& Aulakh, P. S. (2006). Norms- and Control-Based Governance of International Manufacturer - Distributor Relational Exchanges. Journal of International Marketing, 15(1), 92-126.

Gundlach, G. T., \& Achrol R. S. (1993). Governance in Exchange: Contract Law and Its Alternatives. Journal of Public Policy and Marketing, 12(2), 141-55.

Heide, \& John, G. (1992). Do Norms Matter in Marketing Relationships? Journal of Marketing, 56(2), 32-44.

Katsikeas, C. S., Leonidou, L. C., \& Morgan, N. A. (2000). Firm-level export performance assessment: review, evaluation, and development. Journal of the Academy of Marketing Science, 28(4), 493-451.

Lages, L. F., Lages, C., \& Lages, C. R. (2005). Bringing export performance metrics into annual reports: The APEV scale and the PERFEX scorecard. Journal of International Marketing, 13(3), 79-104.

Larson, A. (1992). Network dyads in entrepreneurial settings: A study of the governance of exchange relationships. Administrative Science Quarterly, 37(1), 76-104.

Leonidou, L. C., Katsikeas, C. S., \& Hadjimarcou, J. S. (2002). Building successful export business relationships: A behavioral perspective. Journal of International Marketing, 10(3), 96-115.

Leonidou, L. C., Katsikeas, C. S., \& Samiee, S. (2002). Marketing strategy determinants of export performance: A meta-analysis. Journal of Business Research, 55, 51-67.

Macaulay, S. (1963). Non-contractual relations in business: A preliminary study. American Sociological Review, 28(1), 55-67.

Macneil, I. R. (1980). The new social contract. New Haven, C.T.: Yale University Press. 
Matanda, M. J., \& Freeman, S. (2009). Effect of perceived environmental un-certainty on exporter-importer relationships. International Business Review, 18, 89-107.

Morgan, N. A., Kaleka, A., \& Katsikeas, C. S. (2004). Antecedents of export venture performance: A theoretical model and empirical assessment. Journal of Marketing, 68(1), 90-108.

Samiee, P., \& Walter, G. P. (2003). Relationship marketing in an international context: A literature review. International Business Review, 12(2), 193-214.

Skarmeas, D., \& Robson, M. J. (2008). Determinants of relationship quality in importer-exporter relationships. British Journal of Management, 19(2), 171-184.

Sousa, C. M. P., Martínez-López, F., \& Coelho, F. (2008). The determinants of export performance: A review of the research in the literature between 1998 and 2005. International Journal of Management Reviews, 10(4), 343-374.

Styles, C., \& Ambler, T. (2000). The impact of relational variables on export performance: An empirical investigation in Australia and the UK. Australian Journal of Management, 25(3), 261-282.

Vandaele, D. R., Gemmel, D., \& Lievens, A. (2007). How to govern business services exchanges: Contractual and relational issues. International Journal of Management Reviews, 9(3), 237-258.

Vinh, L., Quester, P., \& Medlin, C. (2007). Service export performance: The role of governance. Retrieved from http://www.conferences.anzmac.org/ANZMAC2007/papers/VLu_1.pdf

Walkenhorst, P., \& Malouche, M. (2006). Trade policy and export performance in Morocco. Retrieved from http://mpra.ub.uni-muenchen.de/23119/

Wheeler, C., Ibeh, K., \& Dimitratos, P. (2008). UK export performance research: Review and implications. International Small Business Journal, 26(2), 207-239.

Williamson, O. E. (1985). The economic institutions of capitalism: Firms, markets, relational contracting. New York: Free Press.

Wu, F., Rudolf, R., Sinkovics, C. T., \& Roath, A. (2007). Overcoming export manufacturers' dilemma in international expansion. Journal of International Business Studies, 37(2), 283-302.

Zou, S., \& Stan, S. (1998). The determinants of export performance: A review of the empirical literature between 1987 and 1997. International Marketing Review, 5, 333-356.

Zou, S., Fang, E., \& Zhao, S. (2003). The effect of export marketing capabilities on export performance: An investigation of Chinese exporters. Journal of International Marketing, 11(4), 32-55.

Zou, S., Taylor, C. R., \& Osland, G. E. (1998). The EXPERF-scale: A cross-national generalized export performance measure. Journal of International Marketing, 6(3), 37-58. 